\title{
KELAYAKAN FINANSIAL REPLANTING TANAMAN KARET DI DESA BATUMARTA 1 KECAMATAN LUBUK RAJA KABUPATEN OGAN KOMERING ULU PROVINSI SUMATERA SELATAN
}

\author{
(FINANCIAL FEASIBILITY OF REPLANTING RUBBER PLANT IN \\ BARUMARTA 1 VILLAGE LUBUK RAJA SUB-DISTRICT OF OGAN \\ KOMERING ULU SOUTH SUMATERA)
}

\author{
Tiara Nisyah, Bambang Sumantri, dan Nusril \\ Jurusan Sosial Ekonomi Pertanian Fakultas Pertanian Universitas Bengkulu
}

\begin{abstract}
This research aim to: 1) to analyze the amount of financial worthiness of rubber plantation as long as economic age in Batumarta 1 Lubuk Raja Ogan Komering Ulu regency. 2) To know the level of sensitivity in replanting rubber to several dominant factors related to finance and advantage in Batumarta 1 Lubuk Raja Ogan Komering Ulu regency. 77 respondents are chosen, about 30 \% from 258 population which have represented population, because the population in Batumarta1 homogeneously relative in rubber plantation system, that is rejuveration system. The sample was chosen by using Simple Random Sampling Method. The research methodology is Survey. While the data is analyzed by worthiness count criteria which consist of Net B/C ratio, Gross B/C ratio, Provitability ratio, Net Present value (NPV), Internal Return Rate(IRR), this valuation done to know the worthiness off rubber replanting. Otherwise, also done the counting of sensitivity experimental. The result shows that rubber replanting in Batumarta 1 can be properly applied and the most sensitive factor is the decresing of selling price, increasing of production cost (fertilizer and total cost before tax)
\end{abstract}

Keywords: Finansial feasibility Rubber Replanting

\section{PENDAHULUAN}

Sektor pertanian memiliki peranan penting dalam perekonomian nasional ini ditandai oleh kontribusinya yang dominan baik dalam Produk Domestik Bruto sebesar $23,4 \%$ maupun dalam lapangan pekerjaan sebanyak $54 \%$. Salah satu subsektor pertanian yang berpotensi untuk dikembangkan di Indonesia adalah sub sektor perkebunan. Salah satu komoditas yang sejak dahulu hingga saat ini memegang peranan seperti tersebut diatas adalah komoditas karet (Tohir, 2008).

Menurut Anthoni (2008), Sumatera Selatan merupakan salah satu provinsi yang memiliki potensi perkebunan karet. Luas perkebunan karet di Sumatera Selatan tahun 2008 sebesar 978 ribu hektar dengan produksi sebesar 722 ribu ton 
(45,36 \% produksi karet Indonesia). Sebesar $91 \%$ dari luasan tersebut $( \pm 845$ ribu hektar) merupakan karet rakyat, sisanya merupakan milik PBN (Perkebunan Negara) dan PBS ( Perkebunan Swasta).

Kontribusi perkebunan karet Sumatera Selatan terhadap PDRB Sumatera Selatan tanpa migas cukup besar yaitu sebesar 10,61 \% dari total PDRB Sumatera Selatan yang bersumber pada seluruh perkebunan dan pertanian yang ada di Sumatera Selatan. Provinsi Sumatera Selatan memilki 13 Kabupaten. Salah satunya adalah Kabupaten Ogan Komering Ulu. Pada Kabupaten ini terdapat 11 Kecamatan yang berpotensi dalam pengembangan karet salah satunya Kecamatan Lubuk Raja yang merupakan salah satu sentra produksi karet tertinggi. Secara umum permasalahan utama perkebunan karet rakyat adalah masih rendahnya produktivitas kebun akibat masih luasnya areal karet tua/rusak sebesar $11,93 \%$ yang perlu segera diremajakan, dan fluktuasi harga jual produksi dan tidak stabilnya harga- harga input. Namun karena lingkungan alam cukup mendukung untuk dikembangkannya tanaman karet ini, maka perlu didorong upaya-upaya untuk melakukan percepatan peremajaan karet. Walaupun disadari bahwa untuk mengembangkan usaha replanting tanaman karet ini dibutuhkan investasi yang relatif besar, oleh sebab itu peneliti tertarik untuk meneliti keadaan ini, dengan cara menganalisis kelayakan finansial penanaman kembali (replanting) karet dan menganalisis sensitivitas beberapa faktor yang paling dominan terhadap tingkat kelayakan terutama menyangkut faktor biaya dan faktor benefit yang akan diperoleh dalam penanaman kembali (replanting) karet tersebut.

Permasalahannya adalah apakah penanaman kembali (replanting) tanaman karet yang diusahakan oleh para petani di Desa Batumarta 1 Kecamatan Lubuk Raja Kabupaten Ogan Komering Ulu Propinsi Sumatera Selatan layak secara finansial untuk diusahakan? Oleh sebab itu, tujuan penelitian ini adalah untuk menganalisis kelayakan finansial dan tingkat sensitivitas penanaman kembali (replanting) tanaman karet selama umur ekonomis di Desa Batumarta 1 Kecamatan Lubuk Raja Kabupaten Ogan Komering Ulu.

\section{METODOLOGI PENELITIAN}

Lokasi penelitian ditentukan dengan sengaja (Purposive) yaitu Desa Batumarta 1 Kecamatan Lubuk Raja. Lokasi ini merupakan salah satu sentra penghasil karet di Kecamatan Lubuk Raja. Pengambilan data dilakukan pada tanggal 1 Maret sampai 22 Maret 2010.

\section{Metode Penentuan Responden}

Populasi dalam penelitian ini adalah petani yang mengusahakan tanaman karet di daerah penelitian. Jumlah petani yang menanam karet sebanyak 258 orang. Jumlah responden ditentukan sebesar 30\% untuk masing-masing umur 
tanaman (Arikunto, 2002). Sampel yang di dapat sebanyak 77 orang. Pemilihan sampel dari populasi ditentukan dengan metode simple random sampling.

\section{Metode Analisis Data}

Untuk menghasilkan kriteria kelayakan digunakan dua metode yaitu metode arus kas yang di diskonto (Discounted Cash Flow Method) dan metode arus kas yang tidak didiskonto (Undiscounted Cash Flow Method). Selanjutnya arus kas yang digunakan juga dibedakan menjadi dua yaitu arus kas tanpa memperhitungkan biaya tenaga kerja dalam keluarga dan arus kas yang memperhitungkan biaya tenaga kerja dalam keluarga. Penjelasan metode analisis lebih rinci adalah sebagai berikut :

\section{Metode Arus kas yang berdiskonto (Discounted Cash Flow Method)}

Analisis arus kas yang didiskonto ini menguraikan 2 (dua) skenario arus kas, yakni:

1. Arus kas berbasis data primer yang diperoleh dari hasil penelitian

Analisis arus kas yang didiskonto dengan basis data primer dari lapangan didasarkan pada asumsi-asumsi sebagai berikut (a) tingkat suku bunga didiskonto adalah $17 \%$, yakni tingkat suku bunga bank yang berlaku untuk peminjaman, (b) umur ekonomis proyek adalah 25 tahun, dan (c) biaya dan manfaat merupakan nilai kini atau nilai riil di lokasi penelitian.

2. Arus kas berbasis data yang bersumber dari tinjauan pustaka

Arus kas yang didasarkan pada asumsi-asumsi sebagai berikut: (a) tingkat suku bunga didiskonto adalah 17\%, yakni tingkat suku bunga bank yang berlaku untuk peminjaman, (b) umur ekonomis proyek adalah 25 tahun, (c) tingkat Biaya dan manfaat rata-rata sesuai dengan pustaka, (d) pada tahun 2009 umur proyek diasumsikan pada saat umur tanaman karet 6 tahun, (e) harga jual bokar berlaku harga pada tahun 2009 untuk umur tanaman 6 tahun dan tahun berikutnya dianggapa konstan, dan (f) harga input (pupuk dan pestisida) yang berlaku untuk umur proyek tahun 0-5 (2004-2008) menggunakan rata-rata tren harga 5 tahun terakhir sedangkan umur proyek 6 tahun menggunkan harga kini dan selanjutnya untuk umur tanaman 7-25 tahun (2010-2022) harga diasumsikan konstan

\section{Metode Arus Kas yang tidak Didiskonto (Undiscounted Cash Flow Method)}

Penggunaan metode ini dengan alasan data arus kas yang digunakan adalah data arus kas yang digunakan adalah data arus kas dari seluruh umur tanaman yang nilainya sudah bersifat nilai kini (presen value) karena bersumber dari data pada saat penelitian berlangsung 
Asumsi-asumsi yang digunakan adalah sebagai berikut: (a) data yang digunakan adalah data di lokasi penelitian, (b) biaya dan manfaat merupakan nilai kini, dan (c) umur ekonomis dari proyek ini adalah 25 tahun.

\section{Analisa Kelayakan Finansial}

Untuk mengetahui layak tidaknya suatu investasi yang sudah dilakukan. Digunakan kriteria investasi menurut Gray dkk (1993), kriteria kelayakan investasi adalah sebagai berikut :

\section{Net Benefit Cost Ratio}

Net Benefit Cost Ratio merupakan angka perbandingan antara jumlah present value (PV) yang positif (sebagai pembilang) dengan jumlah PV yang negatif (sebagai penyebut). Jika nilai Net $B / C>1$, maka suatu usaha tani dikatakan memberikan manfaat dan layak dilaksanakan.

\section{Gross Benefit Cost Ratio (Gross B/C)}

Gross benefit cost ratio merupakan angka perbandingan antara jumlah present value (PV) arus benefit dan jumlah present value (PV) arus biaya. Jika nilai Gross B/C >1, maka suatu usahatani dikatakan menguntungkan dan layak dilaksanakan.

\section{Profitability Ratio (PV'/K)}

Profitability ratio adalah perbandingan antara present value arus sisa benefit dikurang biaya rutin $(\mathrm{O} \& \mathrm{M})$ dengan biaya modal. Jika $\mathrm{PV}^{\prime \prime} / \mathrm{K}>1$ maka usaha tani karet tersebut layak

\section{Net Present Value (NPV)}

Net Present Value adalah cara untuk menghitung selisih antara nilai sekarang dari benefit dengan nilai sekarang dari biaya setelah di discount factor. Jika nilai NPV >0, maka suatu usaha menguntungkan dan layak dilaksanakan

\section{Internal Rate of Return (IRR)}

Internal Rate of Return (IRR) digunakan untuk menghitung tingkat bunga yang menyamakan PV investasi dengan PV Proceeds. Jika IRR > dari tingkat bunga yang berlaku saat usahatani dilakukan, maka usahatani menguntungkan dan layak dilaksanakan. 


\section{Analisis Sensitivitas}

Analisis sensitivitas digunakan untuk melihat apa yang akan terjadi dalam analisa usaha tani replanting tanaman karet apabila terjadi perubahanperubahan faktor yang dominan (manfaat dan biaya). Ketidaktepatan perkiraan biaya dan manfaat itu diantaranya: (a) kenaikan harga pupuk, (b) kenaikan total biaya operasioanal dan pemeliharaan sebelum dimasukkan pajak, dan (c) penurunan harga jual bokar.

\section{PEMBAHASAN}

\section{Karaktearistik Petani}

Karakteristik yang diamati meliputi umur, tingkat pendidikan, pengalaman berusahatani tani tanaman karet, jumlah anggota keluarga, dapat dilihat pada Tabel 1

Tabel 1 Menunjukkan Rata-rata umur petani pada penelitian ini adalah 43,8 tahun dengan kisaran umur antara 26 sampai 58 tahun. Berdasarkan data umur yang dikumpulkan pada umumnya petani berada pada umur produktif sehingga mempunyai potensi yang cukup besar untuk mengembangkan komoditas karet. Di sisi lama pendidikan formal, rata-rata lama pendidikan formal petani sebesar 7,91tahun dengan kisaran antara 4 sampai 17 tahun. Petani karet di Desa Batumarta 1 memiliki tingkat pendidikan formal yang cukup memadai. Sehingga akan mempengaruhi pola pikir dalam pengadopsian teknogi replanting tanaman karet. Lebih jauh, pengalaman usahatani responden berkisar antara 3 sampai 34 dan rata-rata pengalaman usahatani replanting adalah 18,63 tahun. Pengalaman ini akan membantu petani dalam pengambilan keputusan. Seorang petani akan cenderung belajar dari pengalamannya sehingga ia memiliki gambaran seperti apa yang akan dilakukan demi peningkatan produksi.

Tabel 1 juga menunjukkan bahwa semua petani replanting tanaman karet sudah berkeluarga, jumlah anggota keluarga berkisar antara 2-6 orang dengan rata-rata tanggungan 4,06 orang. Jumlah anggota keluarga yang menjadi tanggungan dapat memberikan motifasi bagi petani sebagai kepala keluarga untuk menghasilkan produk seoptimal mungkin supaya mendapat hasil yang dapat memenuhi kebutuhan keluarga. Disisi lain, anggota keluarga yang berusia produktif dapat membantu pengelolaan usahatani. Mereka dapat menyumbangkan tenaga mereka sebagai tenaga kerja dalam keluarga sehingga mengurangi biaya untuk upah kerja 
Tabel.1 Karakteristik Petani Replanting Tanaman Karet Di Desa Batumarta 1 Kecamatan Lubuk Raja, Kabupaten Ogan Komering Ulu Sumatera Selatan 2010

\begin{tabular}{|c|c|c|c|c|}
\hline No & Karakteristik & Rata-rata & kisaran & Persentase $(\%)$ \\
\hline \multirow[t]{7}{*}{1} & Umur & 43,8 & $26-58$ & \\
\hline & - $26-30$ & & & 5,19 \\
\hline & - $31-35$ & & & 9,09 \\
\hline & - $36-40$ & & & 9,09 \\
\hline & - 41-45 & & & 11,69 \\
\hline & - $46-50$ & & & 31,17 \\
\hline & $>50$ & & & 33,77 \\
\hline \multirow[t]{7}{*}{2} & Tingkat pendidikan & 7,91 & $4-12$ & \\
\hline & - Tidak tamat SD & & & 9,09 \\
\hline & - Tamat SD & & & 33,47 \\
\hline & - Tidak tamat SLTP & & & 10,39 \\
\hline & - Tamat SLTP & & & 28,57 \\
\hline & - Tidak tamat SLTA & & & 3,89 \\
\hline & - Tamat SLTA & & & 14,29 \\
\hline \multirow[t]{5}{*}{3} & $\begin{array}{l}\text { Pengalaman usahatani } \\
\text { (Tahun) }\end{array}$ & 18,63 & 3-34 & \\
\hline & - $1-10$ & & & 24,68 \\
\hline & - $11-20$ & & & 29,87 \\
\hline & - $21-30$ & & & 29,87 \\
\hline & $\bullet>30$ & & & 15,58 \\
\hline \multirow[t]{4}{*}{6} & Jumlah anggota keluarga & 4,06 & $2-6$ & \\
\hline & - 1-2 & & & 7,79 \\
\hline & - 3-4 & & & 46,75 \\
\hline & • $5-6$ & & & 45,46 \\
\hline
\end{tabular}

Sumber: Data primer yang diolah. 2010

\section{Penggunaan Faktor Produksi}

Untuk mengetahui penerimaan usahatani replanting tanaman karet yang dilakukan oleh petani maka dilakukan perhitungan biaya produksi dengan menjumlahkan komponen-komponen biaya seperti biaya bibit, biaya pupuk, biaya pestisida, biaya tenaga kerja. Perhitungan biaya produksi usahatani replanting tanaman karet dapat dilihat pada Tabel 2

Tabel 2 menunjukkan bahwa total rata rata biaya produksi yang paling besar dikeluarkan adalah pada basis data lapangan untuk arus kas tunai dan tidak tunai, dengan jumlah yang diperoleh secara berturut turut adalah $\mathrm{Rp} 102$ 216448 dan Rp 230381363 sedangkan pada basis data pustaka lebih kecil untuk arus kas tunai dan tidak tunai diperoleh secara berturut turut adalah Rp 76767 074 dan Rp 224855 323. Perbedaan besaran nilai tersebut disebabkan pada data lapangan pemakaian sarana produksi seperti (pupuk, pestisida, dan tenaga 
kerja, dan lain-lain) melebihi anjuran yang diberikan oleh balai penyuluhan kehutanan dan perkebunan sehingga menambah biaya sedangkan pada data pustaka pemakaian sarana produksi sesuai dengan anjuran sehingga biaya yang dikeluarkan sesuai dengan normalnya.

Tabel 2. Total Rata-Rata Biaya Produksi Usahatani Replanting Tanaman Karet Di Desa Batumarta 1 Selama 25 Tahun.

\begin{tabular}{llrrrr}
\hline \multirow{2}{*}{ No } & \multicolumn{2}{c}{ Uraian } & \multicolumn{2}{c}{ Data Lapangan Rp/Ha } & \multicolumn{2}{c}{ Data pustaka Rp/Ha } \\
\cline { 2 - 5 } & & \multicolumn{1}{c}{ Tunai } & Tidak tunai & \multicolumn{1}{c}{ Tunai } & Tidak tunai \\
\hline 1 & Biaya Bibit & 1631000 & 1631000 & 1631000 & 1631000 \\
2 & Biaya Pupuk & 48533339 & 48533339 & 45456830 & 45456830 \\
3 & Biaya pestisida & 7066952 & 7066952 & 8080000 & 8080000 \\
4 & Biaya pembekuan latek & 709300 & 709300 & 700000 & 700000 \\
5 & Biaya biaya pajak & 232692 & 232692 & 182000 & 182000 \\
6 & Biaya tenaga kerja & 37318167 & 165483082 & 13558167 & 16164616 \\
7 & Biaya penyusutan & 6724998 & 6724998 & 7159077 & 7159077 \\
\hline & Jumlah & 102216448 & 230381363 & 76767074 & 224855323 \\
\hline
\end{tabular}

Sumber: Data primer dan sekunder yang diolah.2010

\section{Biaya Bibit}

Bibit karet yang digunakan oleh para petani adalah bibit yang dihasilkan dengan cara okulasi, yang diperoleh dengan cara membeli dari penangkar bibit. Bibit karet yang di okulasi dengan kombinasi batang bawah menggunakan bibit GT 1, dimana bibit batang bawah ini mempunyai kelebihan akar yang kuat. Sedangkan bibit batang atas menggunakan PR 26, mempunyai kelebihan kulit yang tebal sehingga dapat menghasilkan getah yang lebih banyak. Biaya bibit dikeluarkan pada tahun ke-1. Berdasarkan Tabel 14, maka diketahui bahwa besarnya biaya total rata-rata bibit untuk basis data lapangan dan pustaka dengan arus kas tunai dan tidak tunai yang dikeluarkan oleh petani yaitu sebesar Rp. 1.631.000/Ha. Jumlah bibit yang digunakan per usahataninya ratarata 450 pohon (stek) dengan jarak tanam $3 \times 6$ meter, dengan satu batang bibit stek karet sebesar Rp. 3.500.

\section{Biaya Pupuk}

Untuk tanaman karet yang masih remaja (0-5) tahun pemupukan dilakukan 2 kali setahun, tanaman karet teruna (6-12) tahun dan tanaman dewasa pemupukan dilakukan 3 kali setahun, sedangkan tanaman tua (21-25) tahun pemupukan dilakukan 2 kali setahun. Pemberian pupuk pada tanaman karet harus sesuai dosis, artinya setiap peningkatan umur tanaman karet terjadi penambahan dan penurunan dosis pupuk yang diberikan, perlakuan tersebut dilakukan untuk menambah unsur hara yang dibutuhkan tanaman. Selain itu 
perlakuan pemberian dosis pupuk tersebut harus tergantung dari tanah (Setiawan, 2007).

Berdasarkan Tabel 14 maka dapat diketahui bahwa besarnya total ratarata biaya pupuk yang dikeluarkan oleh petani yaitu untuk pupuk anorganik (pupuk buatan) seperti NPK, TSP, KCL, dan Mikrolatek untuk data lapangan (arus kas tunai dan tidak tunai) sebesar Rp. 48.533.339/Ha, sedangkan untuk data pustaka (tunai dan tidak tunai) sebesar Rp 45456830/Ha. Biaya pupuk pada data lapangan lebih besar dari pada biaya pupuk pada data pustaka. Perbedaan tersebut disebabkan pada data lapangan petani menggunakan pupuk melebihi dosis yang telah dianjurkan oleh balai penyuluhan kehutanan dan perkebunan dan tingkat harga pupuk yang diterima ditingkat petani adalah harga yang berlaku di pasaran. sehingga biaya yang dikeluarkan lebih besar sedangkan pada data pustaka petani menggunakan pupuk sesuai dengan dosis anjuran dan tingkat harga pupuk yang dipakai berdasarkan rata-rata tren harga 5 tahun terakhir.

\section{Biaya Pestisida}

Jenis pestisida yang digunakan petani karet di Desa Batumarta 1 (data lapangan untuk arus kas tunai dan tidak tunai) meliputi herbisida dan fungisida. Pestisida ini digunakan untuk mengatasi hama dan penyakit yang menyerang tanaman karet (Setiawan, 2007). Jenis herbisida yang digunakan petani yaitu Roundup, sedangkan jenis fungisida yang digunakan petani adalah Dithane dan Manzate. Berdasarkan Tabel 14 diketahui bahwa besarnya total rata-rata penggunaan pestisida yang digunakan oleh para petani pada data lapangan sebesar Rp. 7.066.952/Ha. Penggunaan pestisida disesuaikan dengan lahan, selain itu penggunaan pestisida khususnya fungisida diberikan jika tanaman karet terkena penyakit seperti kanker garis, mati kulit, jamur akar putih. Sedangkan untuk data pustaka biaya pestisida hanya memperhitungkan pada penggunaan herbisida, ini diasumsikan tanaman karet tidak terkena penyakit, rata-rata penggunaan pestisida yang digunakan petani untuk data pustaka yaitu Rp. 8.080.000.

Perbedaan besaran nilai antara data lapangan dan data pustaka disebabkan karena pada data lapangan petani tidak menggunakan dosis pestisida sesuai dengan anjuran, artinya jumlah penggunaan pestisida dikurangi dari dosis anjuran/ mengurangi dari dosis sebenarnya sehingga mengurangi biaya. Sedangkan data pustaka dosis penggunaan pestisida sesuai dengan anjuran dari balai penyuluhan perkebunan dan kehutanan, sehingga biaya yang dikeluarkan optimal dan lebih besar dari biaya pestisida pada data lapangan.

\section{Biaya pembekuan lateks}

Jenis pembeku lateks yang digunakan oleh petani adalah tawas. Tawas digunakan oleh petani untuk membekukan lateks dalam cetakan dan mangkuk. Tabel 14 menunjukkan biaya yang dikeluarkan oleh petani basis data lapangan (arus kas tunai dan tidak tunai) dalam penyediaan tawas adalah sebesar Rp. 
709.300/Ha, sedangkan untuk data pustaka (arus kas tunai dan tidak tunai) dalam penyediaan tawas adalah sebesar Rp.700.000/Ha. Perbedaan nilai tersebut disebabkan pada data lapangan petani menggunakan pembeku lateks (tawas) melebihi dosis yang dianjurkan sehingga biaya pembeku lateks untuk data lapangan lebih besar dari data pustaka, diketahui bahwa pada data pustaka penggunaan pembeku lateks sesuai dengan anjuran balai penyuluhan perkebunan dan kehutanan.

\section{Biaya Tenaga Kerja}

Untuk mengetahui penggunaan biaya tenaga kerja luar keluarga per hektarnya dapat dilihat pada Tabel 3.

Tabel 3. Rata-Rata Biaya Penggunaan Tenaga Kerja Pada Usaha Replanting Tanaman Karet

\begin{tabular}{llrrrr}
\hline \multirow{2}{*}{ No } & \multirow{2}{*}{ Komponen Biaya } & \multicolumn{2}{c}{ Data Lapangan Rp/Ha } & \multicolumn{2}{c}{ Data Pustaka Rp/Ha } \\
\cline { 3 - 6 } & & \multicolumn{1}{c}{ Tunai } & Tidak Tunai & \multicolumn{1}{c}{ Tunai } & Tidak Tunai \\
\hline 1 & Pengolahan Tanah & 590.000 & 730.000 & 590.000 & 730.000 \\
2 & $\begin{array}{l}\text { Pembuatan Lubang } \\
\text { Tanam }\end{array}$ & 280.000 & 430.000 & 280.000 & 430.000 \\
& & & & & \\
3 & Penanaman & 222.000 & 306.000 & 222.000 & 306.000 \\
4 & Penyulaman & - & 42.000 & - & 42.000 \\
5 & Pemupukan & 1.973 .500 & 3.873 .750 & 1.973 .500 & 3.873 .750 \\
6 & Pemberantasan Hama & 1.482 .667 & 3.394 .666 & 1.482 .667 & 3.394 .666 \\
7 & Penyadapan & 28.800 .000 & 145.500 .000 & - & 144.000 .000 \\
8 & Pengangkutan & 4.560 .000 & 11.936 .666 & 9.600 .000 & 9.600 .000 \\
\hline & $\quad$ Jumlah & 37.908 .167 & 166.213 .082 & 14.148 .167 & 16.237 .6416 \\
\hline
\end{tabular}

Sumber: Data primer dan sekunder yang diolah.2010

Dalam mengusahakan tanaman karet, selain menggunakan tenaga kerja dalam keluarga, petani juga menggunakan tenaga kerja luar keluarga. Di Desa Batumarta 1 tenaga kerja luar sering disebut buruh tani yang biasa berkelompok. Upah tenaga kerja antara pria dan wanita tidak berbeda yaitu Rp. 30.000 dengan jam kerja maksimal 8 jam.

Tabel 3 menujukkan jumlah biaya tenaga kerja pada arus kas tidak tunai (tenaga kerja dalam dan luar keluarga diperhitungkan sebagai biaya) dengan basis data lapangan lebih besar dari pada arus kas tidak tunai dengan basis data pustaka yaitu diperoleh secara berturut-turut sebesar Rp 166213082/Ha dan Rp 162376416/Ha , sedangkan jumlah tenaga kerja pada arus kas tunai (tenaga kerja luar keluarga yang diperhitungkan sebagai biaya) dengan basis data lapangan lebih besar juga dari pada arus kas tunai data pustaka yaitu diperoleh berturutturut sebesar Rp 37908167/Ha dan Rp 14148167/Ha.

Perbedaan besaran nilai tersebut disebabkan karena penggunaan tenaga kerja pada data lapangan terkadang melebihi dari kebutuhan sedangkan pada 
data pustaka tenaga kerja yang digunakan sesuai dengan kebutuhan. Tingginya biaya tenaga kerja pada arus kas tunai dan tidak tunai basis data lapangan dan pustaka adalah pada kegiatan penyadapan. Kegiatan penyadapan memerlukan hari kerja yang lebih banyak jika dibandingkan dengan kegiatan yang lain, penggunaan tenaga kerja yang banyak pada saat penyadapan karena pohon karet yang sudah menghasilkan harus disadap hampir setiap hari.

Dengan adanya petani yang mengusahakan usahatani replanting tanaman karet ini dapat memberikan pekerjaan pada buruh tani yang ada di Desa Batumarta 1, sehingga di desa taersebut sekarang banyak penduduk yang berdomisili untuk sementara. Mereka merupakan tenaga kerja buruh tani.

\section{Biaya Alat Pertanian}

Dalam usahatani replanting tanaman karet petani menggunakan alat seperti cangkul, sabit, parang, hand sprayer, pisau sadap, mangkuk, talang, kawat, tali kawat, cetakan dan tangga. Biaya penggunaan alat pertanian ini dihitung dalam biaya penyusutan per tahun untuk (cangkul, sabit, parang dan hand sprayer), sedangkan alat yang lain diperhitungkan dalam biaya penyusutan mulai dari umur 6-25 tahun. Untuk mengetahui biaya alat dalam usaha replanting tanaman karet dapat dilihat pada Tabel 4.

Tabel 4. Biaya Penyusutan Alat-Alat Dalam Usaha Replanting Tanaman Karet Basis Data Lapangan Dan Pustaka Selama Umur Ekonomis

\begin{tabular}{lcc}
\hline \multirow{2}{*}{ Nama Alat } & \multicolumn{2}{c}{ Biaya penyusutan Rp/Ha } \\
\cline { 2 - 3 } Cangkul & Data lapangan & Data Pustaka \\
Sabit & 271.089 & 489.449 \\
Parang & 329.701 & 351.693 \\
HandSprayer & 269.932 & 297.575 \\
Mangkuk & 767.028 & 915.360 \\
Pisau Sadap & 2.295 .922 & 2.400 .000 \\
Talang & 193.165 & 200.000 \\
Kawat & 310.248 & 315.000 \\
Tali Kawat & 1.228 .678 & 1.350 .000 \\
Cetakan & 169.099 & 180.000 \\
Tangga & 773.470 & 600.000 \\
\hline Jumlah & 116.666 & 60.000 \\
\hline
\end{tabular}

Sumber: Data primer dan sekunder yang diolah.2010

Dalam perhitungan penyusutan ini adalah harga awal dikurangi dengan harga akhir dibagi dengan umur ekonomis. Besarnya total rata-rata biaya penyusutan alat-alat untuk data lapangan sebesar Rp.6.724.998/Ha dan untuk data pustaka sebesar Rp.7.159.077/Ha selama 0-25 tahun. Perbedaan besaran nilai tersebut disebabkan dari harga alat, umur ekonomis dan jumlah unit. 


\section{Biaya Pajak Lahan}

Jumlah pajak yang dibebankan kepada para petani karet selalu sama pada setiap tahunnya. Besarnya biaya pajak sangat tergantung dari luas lahan yang dimiliki oleh para petani. Semakin luas lahannya maka akan semakin besar pula pajak yang harus dikeluarkan oleh petani tersebut. Besarnya biaya pajak yang dikeluarkan oleh petani setiap tahunnya yaitu Rp. 700.000/Ha.

\section{Total Rata-Rata Produksi dan Penerimaan}

Untuk mengetahui rata-rata nilai produksi dan besarnya penerimaaan usahatani replanting karet dapat dilihat pada Tabel 5.

Tabel 5. Total Rata-Rata Produksi Dan Penerimaan Usahatani Replanting Tanaman Karet Di Desa Batumarta 1, Selama 25 Tahun

\begin{tabular}{llcc}
\hline No & \multicolumn{1}{c}{ Uraian } & Data lapangan & Data Pustaka \\
\hline 1 & Produksi (Kg) & 4.819 & 4.805 \\
2 & Harga (Rp) : & 8.590 & 9.000 \\
3 & Penerimaan (Rp) & $39.290 .410,4$ & 43.245 .000 \\
\hline
\end{tabular}

Sumber: Data primer dan sekunder yang diolah.2010

Tabel 5 menunjukkan bahwa total rata-rata produksi mulai dari umur 6-25 tahun pada data lapangan yaitu $4819 \mathrm{Kg} / \mathrm{Ha}$ dan rata-rata produksi pada data pustaka yaitu $4805 \mathrm{Kg} / \mathrm{Ha}$. Tanaman karet berproduksi pada awal tahun ke enam, pada tahun ke lima pohon karet sudah menghasilkan getah tetapi belum baik untuk disadap.

Penerimaan dapat diketahui dengan cara mengalikan jumlah produksi (konsumsi yang dijual) dengan harga. Dalam penelitian ini penerimaan yang dimaksud adalah penerimaan yang diperoleh dari penjualan hasil bokar. Total rata-rata penerimaan usahatani replanting tanaman karet pada data lapangan dari umur 6-25 tahun yaitu Rp.39.290.410,4/Ha, sedangkan pada data pustaka yaitu sebesar Rp.43.245.000/Ha. Penerimaan pada data pustaka lebih besar dari data lapangan, karena pada data lapangan harga jual bokar yang diterima di tingkat petani yaitu sebesar Rp.8.590/Kg lebih kecil dari pada harga yang berlaku secara nasional (data pustaka) yaitu sebesar Rp.9.000/Kg. Selain itu perbedaan jumlah penerimaan tersebut disebabkan adanya perbedaan dalam teknis dan frekuensi penyadapan.

\section{Analisis Kelayakan Finansial}

Dalam analisis kelayakan usahatani replanting tanaman karet ini berpedoman pada data lapangan dan data pustaka yang berhubungan dengan kegiatan usahatani replanting tanaman karet di Desa Batumarta 1 Kecamatan Lubuk Raja Kabupaten OKU Sumatera Selatan, dan beberapa litaratur yang ada. 
Analisis usahatani ini menggunakan patokan lahan. Tenaga kerja relatif yang digunakan memiliki keterampilan sederhana. Disini juga dikemukakan bahwa angka-angka yang tertera atau tertulis pada lampiran dan uraian tersebut merupakan angka yang didasarkan pada usahatani replanting tanaman karet.

\section{Biaya Investasi}

Investasi merupakan sejumlah uang yang digunakan oleh petani sebagai modal awal dalam berusahatani. Jadi secara umum, segala bentuk modal yang digunakan untuk berbagai kegiatan yang dilakukan selama usaha atau proyek tersebut belum menghasilkan maka modal tersebut disebut investasi. Biaya investasi pada tahun ke nol sampai dengan usahatani tersebut menghasilkan, terdiri dari biaya bangunan, pengelolaan lahan, pembuatan ajir, pagar, lubang tanam, bibit karet, peralatan, pupuk, pestisida, dan pemeliharaan tunai dan tidak tunai. Rata-rata investasi usahatani replanting tanaman karet dengan basis data lapangan dan data pustaka disajikan dalam Tabel 6 berikut.

Tabel 6. $\quad$ Rata-Rata Biaya Investasi Usahatani Replanting Tanaman Karet Basis Data Lapangan Dan Data Pustaka (Arus Kas Tunai Dan Tidak Tunai)

\begin{tabular}{llrrrr}
\hline \multirow{2}{*}{ No } & \multirow{2}{*}{ Komponen Biaya } & \multicolumn{2}{c}{ Data Lapangan Rp/Ha } & \multicolumn{2}{c}{ Data Pustaka Rp/Ha } \\
\cline { 3 - 6 } & & \multicolumn{1}{c}{ Tunai } & Tidak Tunai & \multicolumn{1}{c}{ Tunai } & Tidak Tunai \\
\hline 1 & Pembuatan Pondok/ & 1.066 .666 & 1.066 .666 & 1.066 .666 & 1.066 .666 \\
& Bangunan & 1.116 .667 & 1.116 .667 & 1.116 .667 & 1.116 .667 \\
2 & Pembuatan Pagar & 210.000 & 210.000 & 210.000 & 210.000 \\
3 & Pembuatan Ajir & 590.000 & 730.000 & 590.000 & 730.000 \\
4 & Pengolahan Lahan & 1.631 .000 & 1.631 .000 & 1.631 .000 & 1.631 .000 \\
5 & Bibit Karet & 504.077 & 504.077 & 504.077 & 504.077 \\
6 & Penyusutan Peralatan & 10.455 .633 & 10.455 .633 & 5.691 .830 & 5.691 .830 \\
7 & Pupuk & 2.021 .906 & 2.021 .906 & 1.700 .000 & 1.700 .000 \\
8 & Pestisida & 1.528 .167 & 2.643 .916 & 1.528 .167 & 2.643 .916 \\
9 & Pemeliharaan & 46.317 & 46.317 & 42.000 & 42.000 \\
10 & Pajak & 19.170 .433 & 20.426 .182 & 14.080 .407 & 15.336 .156 \\
\hline
\end{tabular}

Sumber: Data primer dan sekunder yang diolah.2010

Berdasarkan Tabel 6 bahwa pembuatan pondok, pembuatan pagar, pembuatan ajir, pengelolaan lahan, pestisida, pupuk, penyusutan dan pemeliharaan dimasukkan sebagai biaya investasi selama usahatani belum menghasilkan yaitu sampai tahun ke lima yang termasuk biaya pemeliharaan yaitu : pembuatan lubang tanam, penanaman, penyulaman, pemupukan, pemberantasan hama dan pajak, Tabel 6 menunjukkan besar rata-rata biaya investasi tunai dan tidak tunai basis data lapangan yang dikeluarkan oleh petani secara berturut turut sebesar Rp.19.170.433/Ha dan Rp.20.426.182/Ha, 
sedangkan besar rata-rata biaya investasi tunai dan tidak tunai basis data pustaka yang dikeluarkan oleh petani secara berturut turut sebesar Rp.14.080.407/Ha dan Rp.15.336.156/Ha. Jumlah investasi data lapangan lebih besar dari data pustaka, adapun jumlah biaya investasi terbesar adalah pada data lapangan arus kas tidak tunai dengan biaya investasi terbesar ada pada biaya pupuk sebesar Rp. 10.455.633/Ha, sedangkan biaya terkecil adalah pajak yaitu sebesar 46.317/Ha . besarnya biaya pupuk untuk usahatani replanting tanaman karet disebabkan penggunaan pupuk tidak sesuai dengan dosis anjuran untuk usahatani replanting tanaman karet sehingga menyebabkan pemborosan terhadap biaya yang dikeluarkan.

\section{Biaya Operasional dan Pemeliharaan}

Biaya operasional dan pemeliharaan selama umur ekonomis usahatani replanting tanaman karet tiap tahunnya tidak sama. Biaya operasional dan pemeliharaan mulai terhitung sejak usahatani replanting tanaman karet mulai menghasilkan yaitu dimulai pada tahun ke enam. Biaya operasional dan pemeliharaan meliputi : pupuk, pestisida, pajak, pembekuan latek dan pemeliharaan tunai dan tidak tunai (pemupukan sampai pengangkutan). Untuk lebih jelasnya dapat dilihat pada Tabel 7 berikut ini.

Tabel 7. Rata-Rata Biaya Operasional Dan Pemeliharaan Usahatani Replanting Tanaman Karet Basis Data Lapangan Dan Pustaka

\begin{tabular}{llrrrr}
\hline \multirow{2}{*}{ No } & \multirow{2}{*}{ Komponen Biaya } & \multicolumn{2}{c}{ Data Lapangan } & \multicolumn{2}{c}{ Data Pustaka } \\
\cline { 3 - 5 } & & \multicolumn{1}{c}{ Tunai } & \multicolumn{1}{c}{ Tidak Tunai } & \multicolumn{1}{c}{ Tunai } & \multicolumn{1}{c}{ Tidak Tunai } \\
\hline 1 & Pupuk & 38.077 .706 & 38.077 .706 & 39765000 & 39765000 \\
2 & Pestisida & 5.045 .046 & 5.045 .046 & 6380000 & 6380000 \\
3 & Pembekuan latek & 709.300 & 709.300 & 700000 & 700000 \\
4 & Pajak & 186.375 & 186.375 & 140000 & 140000 \\
5 & Pemeliharaan & 35.790 .000 & 162.839 .166 & 12030000 & 159002500 \\
\hline & Jumlah & 79.808 .427 & 206.857 .593 & 59.015 .000 & 205.987 .500 \\
\hline
\end{tabular}

Sumber: Data primer dan sekunder yang diolah.2010

Tabel 7 menunjukkan ada perbedaan jumlah biaya operasional dan pemeliharaan yang dikeluarkan pada basis data lapangan dan pustaka untuk arus kas tunai dan tidak tunai. Berdasarkan Tabel 7, biaya opersional dan pemeliharaan data lapangan lebih besar yaitu sebesar Rp 206.857.593/Ha. Dari pada data pustaka yaitu sebesar Rp 205.987.500/Ha.Besaran biaya tersebut yang paling mendominasi adalah pada komponen biaya pemeliharaan. Pemeliharaan bertujuan agar tanaman karet dapat berproduksi secara optimal. Besarnya ratarata biaya pemeliharaan tidak tunai data lapangan yaitu Rp. 162.839.166/Ha dan data pustaka sebesar Rp 159.002.500/Ha, biaya ini yang dikeluarkan mulai dari tahun ke-0 sampai dengan tahun ke-25. 


\section{Analisis Kelayakan Finansial}

Menurut Djazuli (2009) analisis kelayakan finansial merupakan analisis yang didasarkan pada harga-harga riil dari apa yang sebenarnya terjadi. Hal yang akan dianalisis adalah biaya dan manfaat dari investasi. Analisis investasi digunakan untuk mengetahui layak atau tidaknya usahatani replanting tanaman karet.

Dalam analisis kelayakan ini diterapkan dua metode (Discounted Cash Flow Method dan Undiscounted Cash Flow Method). Arus kas yang digunakan dibedakan menjadi arus kas tanpa memperhitungkan tenaga kerja (tunai) dalam keluarga dan arus kas yang memperhitungkan tenaga kerja dalam keluarga (tidak tunai). Untuk lebih jelasnya dapat dilihat pada Tabel 8.

Tabel 8. Perincian Hasil Kriteria Investasi Dengan Menggunakan Beberapa Metode

\begin{tabular}{|c|c|c|c|c|c|}
\hline \multirow[b]{2}{*}{ No } & \multirow{2}{*}{$\begin{array}{c}\text { Metode Arus } \\
\text { Kas }\end{array}$} & \multirow{2}{*}{$\begin{array}{c}\text { Kriteria } \\
\text { Kelayakan }\end{array}$} & \multicolumn{2}{|c|}{ Arus Kas } & \multirow{2}{*}{$\begin{array}{l}\text { Persentase } \\
\text { Selisih (\%) }\end{array}$} \\
\hline & & & Tunai & Tidak tunai & \\
\hline \multirow[t]{6}{*}{1} & Discounted Cash & Net B/C & 6,89 & 4,95 & 28,15 \\
\hline & Flow Method & Gross B/C & 3,60 & 2,06 & 42,77 \\
\hline & Berbasis data & PV" & 5,21 & 3,81 & 26,87 \\
\hline & lapangan & NPV & 61267962 & 43670889 & 28,72 \\
\hline & & IRR & $46,39 \%$ & $37,53 \%$ & 8,86 \\
\hline & Rata-rata & & & & 27,07 \\
\hline \multirow[t]{6}{*}{2} & Discounted Cash & Net B/C & 10,75 & 7,26 & 32,46 \\
\hline & Flow Method & Gross B/C & 4,34 & 2,18 & 49,76 \\
\hline & Berbasis data & PV" & 7,03 & 4,91 & 30,15 \\
\hline & pustaka & NPV & 66751734 & 46973203 & 29,62 \\
\hline & & IRR & $57,25 \%$ & $42,53 \%$ & 14,72 \\
\hline & Rata-rata & & & & 31,34 \\
\hline \multirow[t]{6}{*}{3} & Undiscounted & Net B/C & 47,28 & 36,96 & 21,82 \\
\hline & Cash Flow & Gross B/C & 7,95 & 3,58 & 54,96 \\
\hline & Method & PV" & 29,80 & 23,63 & 20,70 \\
\hline & Berbasis data & NPV & 731432397 & 603127482 & 17,54 \\
\hline & lapangan & IRR & $46,39 \%$ & $37,53 \%$ & 8,86 \\
\hline & Rata-rata & & & & 24,77 \\
\hline
\end{tabular}

Sumber: Data primer dan sekunder diolah.2010.

Berdasarkan tabel 8 maka dapat dijelaskan bahwa Discounted Cash Flow Method dengan basis data lapangan dan data pustaka serta Undiscounted Cash Flow Method basis data lapangan memiliki keputusan yang sama yaitu layak secara finansial dan menguntungkan artinya usaha replanting tanaman karet dapat memberikan keuntungan bagi petani dan keuntungan usaha replanting tanaman karet mampu mengembalikan modal yang diinvestasikan selama umur ekonomis. Ini dilihat dari nilai kriteria investasi (Net B/C ratio, Gross B/C 
ratio, $\left.P V^{\prime \prime} / K\right)$ lebih besar dari 1, nilai NPV lebih besar dari 0 dan nilai IRR lebih besar dari tingkat suku bunga bank yang berlaku yaitu $17 \%$.

Nilai kriteria investasi untuk Discounted Cas Flow Method basis data lapangan arus kas tunai dan tidak tunai secara berturut-turut sebagai berikut : nilai Net B/C sebesar 6,89 dan 4,95, nilai Gross B/C ratio 3,60 dan 2,06, nilai $P V^{\prime \prime} / K$ sebesar 5,21 dan 3,81 sedangkan nilai NPV 61267962 dan 43670889 dan IRR sebesar 46,39 \% dan 37,53\%, Discounted Cash Flow Method yang berbasis data pustaka untuk arus kas yang tunai dan tidak tunai nilai kriteria investasi secara berturut-turut sebagai berikut nilai $N e t B / C$ sebesar 10,75 dan 7,26, nilai Gross $B / C$ ratio 4,34 dan 2,18 , nilai $P V^{\prime \prime} / K$ sebesar 7,03 dan 4,91 sedangkan nilai $N P V$ 66751734 dan 46973203 dan IRR sebesar $57,25 \%$ dan $42,53 \%$.

Undiscounted Cash Flow Method yang berbasis data lapangan untuk arus kas yang tunai dan tidak tunai memiliki nilai kriteria investasi secara berturutturut sebagai berikut nilai $\mathrm{Net} B / \mathrm{C}$ sebesar 47,28 dan 36,96, nilai Gross B/C ratio 7,95 dan 3,58, nilai $P V^{\prime \prime} / K$ sebesar 29,80 dan 23,63 sedangkan nilai $N P V$ 731432397 dan 603127482 dan IRR sebesar $46,39 \%$ dan 37,53\%.

Tabel 8 juga menunjukkan tingkat kelayakan yang paling tinggi adalah metode Undiscounted Cash Flow Method arus kas tunai dan tidak tunai kemudian diikuti dengan Discounted Cash Flow Method basis pustaka arus kas tunai, Discounted Cash Flow Method basis data lapangan arus kas tunai. Selanjutnya Discounted Cash Flow Method basis data pustaka arus kas tidak tunai dan terakhir Discounted Cash Flow Method basis data lapangan arus kas tidak tunai. Adapun perbedaan tingkat kelayakan tersebut di sebabkan oleh dari besaran biaya dan manfaat yang digunakan.

Pada Discounted Cash Flow Method data lapangan tunai dan tidak tunai memiliki tingkat kelayakan tinggi karena arus kas yang digunakan tidak di Discount sehingga nilai kriteria investasi dan NPV yang didapatkan besar. Namun pada Undiscounted Cash Flow Method ini arus kas tunai lebih besar dari pada arus kas tidak tunai. Ini disebabkan karena pada arus kas tunai tidak memperhitungkan tenaga kerja dalam keluarga, rata-rata penurunan jumlah nilai kriteria investasi untuk arus kas tunai dan tidak tunai sebesar $24,78 \%$, yang artinya jika arus kas dalam pengukuran kelayakan finansial tidak memperhitungkan tenaga kerja dalam keluarga maka memberikan tingkat keuntungan lebih besar yang mencapai $24,77 \%$ dari pada memperhitungkan tenaga kerja dalam keluarga.

Discounted Cash Flow Method basis data pustaka tingkat kelayakannya lebih tinggi dari pada Discounted Cash Flow Method data lapangan. Ini disebabkan karena penggunaan sarana produksi yang digunakan dan manfaat yang didapatkan. Pada data pustaka petani menggunakan sarana produksi sesuai dengan anjuran dan sesuai dengan kebutuhan. Sedangkan pada data lapangan petani menggunakan sarana produksi melebihi dosis anjuran dan melebihi dari kebutuhan sehingga ini menambah biaya. Discounted Cash Flow Method data pustaka dan lapangan arus kas tunai lebih besar dari pada arus kas tidak tunai. Persentase perbandingan penurunan manfaat untuk Discounted 
Cash Flow Method basis data pustaka sebesar 31,34\%, ini artinya jika petani memperhitungkan tenaga kerja dalam keluarga mengurangi keuntungan sebesar $31,34 \%$ sedangkan persentase perbandingan penurunan manfaat untuk Discounted Cash Flow Method data lapangan sebesar 27,07\%. Ini artinya kontribusi tenaga kerja dalam keluarga dapat menurunkan keuntungan sebesar $27,07 \%$. Jadi dari penjelasan maka usaha replanting tanaman karet akan lebih menguntungkan jika tenaga kerja dalam keluarga tidak diperhitungkan sebagai biaya.

\section{Analisis Sensitivitas}

Analisis sensitivitas ( Tabel 9) bertujuan untuk melihat apa yang akan terjadi dengan analisis investasi usahatani replanting tanaman karet jika ada perubahan-perubahan dalam perhitungan biaya dan penerimaan. Di dalam analisis sensitivitas setiap kemungkinan-kemungkinan yang akan terjadi harus dicoba. Hal ini penting karena adanya kemungkinan dengan meningkatnya produksi penawaran akan bertambah sehingga harga akan menurun. Disamping itu dengan adanya inflasi terhadap harga-harga barang akan mempengaruhi perubahan terhadap peningkatan biaya operasional. Ini berarti, tiap kali ada perubahan harus diadakan analisis kembali terhadap penerimaan yang diperoleh dan biaya yang dikeluarkan, karena analisis usahatani replanting tanaman karet ini didasarkan pada taksiran-taksiran yang banyak mengandung ketidakpastian tentang apa yang akan terjadi di masa yang akan datang yang berhubungan dengan biaya, penerimaan, adanya perubahan hasil dan harga.

Dalam analisis sensitivitas ini dilihat dari dua macam arus kas. Arus kas pertama, dalam kondisi tenaga kerja dalam keluarga tidak diperhitungkan, arus kas kedua dalam kondisi tenaga kerja dalam dan luar diperhitungkan sehingga dilihat bagaimana jika harga pupuk naik, total biaya operasional dan pemeliharaan tidak termasuk pajak naik serta harga jual produksi menurun.

Analisis sensitivitas ini juga dilakukan pada masing-masing ketiga metode yaitu discounted cash flow method dan undiscounted cash flow method (data lapangan yang diolah) serta discounted cash flow Method (data pustaka yang diolah).

Berdasarkan Tabel 9 ketiga metode tersebut dengan arus kas yang berbeda dan basis data yang berbeda ternyata faktor-faktor dominan (pupuk, biaya operasional dan pemeliharaan serta harga produksi) tidak memiliki pengaruh yang berarti terhadap usaha replanting tanaman karet. Ketidaksensitifan faktorfaktor tersebut khususnya untuk sarana produksi disebabkan oleh pemerintah masih memberikan subsidi untuk petani dalam pengunaan sarana produksi seperti pupuk, dan selanjutnya untuk ketidaksensitifan harga jual bokar karena penerimaan usaha replanting tanaman karet juga ditentukan oleh produktivitas tanaman karet. Artinya walaupun harga jual karet turun tetapi produktivitas tinggi, usaha replanting tanaman karet masih menguntungkan.Namun dari ketiga faktor dominan tersebut penurunan harga jual bokr yang paling sensitif. 
Tabel 9. Analisis Sensitivitas Pada 3 Metode

\begin{tabular}{|c|c|c|c|c|}
\hline \multirow[b]{2}{*}{ No } & \multirow[b]{2}{*}{ Keterangan } & \multicolumn{3}{|c|}{ Komponen Perubahan } \\
\hline & & $\begin{array}{l}\text { Penurunan } \\
\text { harga jual } \\
\text { bokar }\end{array}$ & $\begin{array}{c}\text { Kenaikan } \\
\text { Harga } \\
\text { Pupuk }\end{array}$ & $\begin{array}{c}\text { Kenaikan total biaya } \\
\text { O \& M Sebelum } \\
\text { pajak }\end{array}$ \\
\hline I & Data lapangan diolah & & & \\
\hline A & Metode Discounted & & & \\
\hline 1 & Tunai & 77 & 500 & 350 \\
\hline 2 & Tidak tunai & 55 & 350 & 125 \\
\hline B & Metode Undiscounted & & & \\
\hline 1 & Tunai & 89 & 1550 & 800 \\
\hline 2 & Tidak tunai & 73 & 1250 & 175 \\
\hline II & Data pustaka diolah & & & \\
\hline & Metode Discounted & & & \\
\hline 1 & Tunai & 81 & 770 & 500 \\
\hline 2 & Tidak tunai & 57 & 500 & 150 \\
\hline
\end{tabular}

Sumber data primer dan sekunder diolah 2010

Untuk ketiga metode tersebut secara berturut-turut dapat dilihat dari besarnya persentase masing-masing skenario diantaranya adalah sebagai berikut:

1. Discounted Cash Flow Method berbasis data lapangan

Discounted Cash Flow Method. Dengan arus kas tunai penurunan harga produksi dapat ditoleransi sebesar kurang dari 77\%, kenaikan harga pupuk sebesar kurang dari $500 \%$, serta kenaikan biaya total (operasional dan pemeliharaan sebelum pajak) sebesar kurang dari 350\%, sedangkan untuk arus kas tidak tunai penurunan harga produksi dapat ditoleransi sebesar kurang dari 55\%, kenaikan harga pupuk sebesar kurang dari 350\%, serta kenaikan biaya total (operasinal dan pemeliharaan sebelum pajak) sebesar kurang dari $125 \%$.

2. Discounted Cash Flow Method berbasis data pustaka

Discounted Cash Flow Method Dengan arus kas tunai penurunan harga produksi dapat ditoleransi sebesar kurang dari $81 \%$, kenaikan harga pupuk sebesar kurang dari $770 \%$ serta kenaikan biaya total (operasional dan pemeliharaan sebelum pajak) sebesar kurang dari 500\%, sedangkan untuk arus kas tidak tunai penurunan harga produksi dapat ditoleransi sebesar kurang dari $57 \%$, kenaikan harga pupuk sebesar kurang dari $500 \%$, serta kenaikan biaya total (operasional dan pemeliharaan sebelum pajak) sebesar kurang dari $150 \%$.

3. Undiscounted cash Flow Method berbasis data lapangan 
Undiscounted Cash Flow Method Dengan arus kas tunai penurunan harga produksi dapat ditoleransi sebesar kurang dari 89\%, kenaikan harga pupuk sebesar kurang dari $1550 \%$ serta kenaikan biaya total (operasional dan pemeliharaan sebelum pajak) sebesar kurang dari $800 \%$ sedangkan untuk arus kas tidak tunai penurunan harga produksi dapat ditoleransi sebesar kurang dari 73\%, kenaikan harga pupuk sebesar kurang dari $1250 \%$, serta biaya total (operasinal dan pemeliharaan sebelum pajak) sebesar kurang dari $175 \%$.

Dari masing-masing uraian ketiga metode tersebut, alternatif keputusan akan berubah jika persentase penurunan harga produksi dan kenaikan harga pupuk serta kenaikan biaya total (operasional dan pemeliharaan sebelum pajak) tersebut sama dengan atau melebihi dari persentase-persentase tersebut maka usaha replanting tanaman karet tidak layak lagi karena mengalami kerugian, ini terlihat dari nilai kriteria investasinya (Net B/C Ratio, Gross B/C Ratio, Profitability Ratio) kurang dari 1 (satu) serta nilai IRR nya lebih kecil dari tingkat suku bunga bank yang berlaku.

\section{KESIMPULAN DAN SARAN}

\section{Simpulan}

Berdasarkan hasil pembahasan yang telah di lakukan maka dapat ditarik kesimpulan sebagai berikut:

1. Usahatani replanting tanaman karet yang diusahakan oleh petani di Desa Batumarta 1 secara finansial layak untuk tetap diusahakan jika pupuk yang digunakan mendapatkan subsidi

2. Berdasarkan analisis sensitivitas faktor-faktor dominan (pupuk, biaya operasional dan pemeliharaan serta harga produksi) tidak memiliki pengaruh yang berarti terhadap usaha replanting tanaman karet. Ketidak sensitifan faktor tersebut dilihat dari besarnya batas toleransi

\section{Saran}

Petani karet Di Desa Batumarta 1 diharapkan dapat meningkatkan mutu dan kualitas bokar yang dihasilkan dengan cara mengatur frekuensi penyadapan dan mengurangi penggunaan bahan pembeku lateks yang berlebihan. Selain itu petani karet di Desa Batumarta 1 diharapkan menggunakan sarana produksi sesuai dengan anjuran sehingga biaya yang dikeluarkan optimal serta petani karet harus lebih peka terhadap fluktuasi harga sarana produksi. Sedangkan bagi pemerintah, kebijakan subsidi pupuk terhadap program peremajaan karet rakyat dan menjaga stabilitas harga akan sangat penting utuk meningikatkan kesejahteraan petani karet 


\section{DAFTAR PUSTAKA}

Anthoni, M. 2008. Pola Pemanfaatan Dana Revitalisasi Perkebunan di Tingkat Kabupaten. Makalah Seminar Nasional Strategi Pengembangan Agribisnis Karet Dalam Rangka Menunjang Revitalisasi Perkebunan di Sumatera Selatan. Forum Bersama Pembangunan Perkebunan, Sumsel

Arikunto, Suhartini. 2002. Prosedur Penelitian. Renika Citra. Surabaya

Djajuli, N. 2009. Analisis Finansial Pengolahan Surimi dengan Skala Modern dan Semi-modern. Jurnal Pengolahan Hasil Perikanan Indonesia 12(2):102114.

Gray, C. Simanjutak. 1993. Pengantar Evaluasi Proyek Edisi Kedua. Gramedia. Jakarta

Setiawan, D.H. dan Andoko. 2007. Petunjuk Lengkap Budidaya Karet. Edisi revisi. PT Agro Media Pustaka, Jakarta.

Tohir, K. 2008. Seuntai Pengetahuan tentang Usaha Tani Indonesia Bagian 1.Bina Aksara, Jakarta 
ISSN: 1412-8837

AGRISEP Vol. 11 No. 1 Maret 2012 Hal: 78 - 96 | 97 